\title{
Kişilik Özelliklerinin Pozitif ve Negatif Duygular Üzerine Etkisinin Yapısal Eşitlik Modellemesiyle İncelenmesi
}

\author{
Examining the Effects of Personality Traits on Positive and Negative Affect by \\ Structural Equation Modeling
}

\author{
Dr. Öğr. Üyesi Fatma KORKMAZ (D) ${ }^{1}$, Dr. Öğr. Üyesi Fatih Ferhat ÇETINKAYA (iD)2
}

\begin{abstract}
Öz
Bu çalışmada, beş faktör kişilik kuramı çerçevesinde değerlendirilen kişilik özelliklerinin pozitif ve negatif duygulara etkisinin incelenmesi amaçlanmaktadır. Bu kapsamda ilk olarak kişilik kavramı ve beş faktör kişilik özellikleri ile pozitif ve negatif duygulara ilişkin kavramsal ve kuramsal altyapı sunulmakta, daha sonrasında araştırma modeline ilişkin yapılan anket çalışması ile ilgili bulgu ve sonuçlara yer verilmektedir. Araştırma örneklemi Kırşehir ilinde faaliyet gösteren özel sektör kuruluşlarının 463 çalışandan oluşmaktadır. Araştırma verileri 02/07/2020-01/09/2020 tarihleri arasında toplanmıştır. Yüz yüze anket yöntemi ve ölçekler kullanılarak toplanan veriler SPSS 22.0 ve AMOS 24.0 istatistik paket programlarında analiz edilmiştir. Araştırma model testi kapsamında yapısal eşitlik modellemesi uygulanmıştır. Araştırma sonucunda elde edilen bulgulara göre, beş faktör kişilik özelliklerinin pozitif duygular üzerinde istatistiksel açıdan anlamlı ve olumlu yönde yüksek düzeyde etkisinin olduğu, pozitif duyguların \%48'inin beş faktör kişilik özellikleri ile açıklanabileceği (Standardize $\beta=0.690, \mathrm{R}^{2}=0.476$, $\mathrm{p} \leq 0.05$ ), beş faktör kişilik özelliklerinin negatif duygular üzerinde ise istatistiksel açıdan anlamlı ve negatif yönde düşük düzeyde etkisinin olduğu, negatif duygulardaki azalışın \%9'unun beş faktör kişilik özellikleri ile açıklanabileceği (Standardize $\beta=-0.292, \mathrm{R}^{2}=0.085, \mathrm{p} \leq 0.05$ ) gözlenmiştir.
\end{abstract}

Anahtar Kelimeler: Kişilik yapısı, beş faktör kişilik özellikleri kuramı, pozitif duygular, negatif duygular, yapısal eşitlik modellemesi

Makale Türü: Araştırma

\begin{abstract}
In this study, it is aimed to examine the effects of personality traits that is evaluated within the framework of the five factor personality theory on positive and negative affect. In this context, first of all, the concept of personality and the five-factor personality traits and the conceptual and theoretical background related to positive and negative affect are included, and then the findings and results related to the survey study conducted within the scope of the research model are presented. The sample of this study consists of 463 employees of private sector organizations operating in Kirsehir. The research data were collected between the dates $02 / 07 / 2020$ and $01 / 09 / 2020$. The data collected by using face to face survey method and scales were analyzed by using SPSS 22.0 and AMOS 24.0 statistical package programs. Structural equation modeling was used for the research model test. As a result of the findings obtained from the study, it was found that the five-factor personality traits has a statistically significant and a positive effect on positive affect, and $48 \%$ of positive affect can be explained by the five-factor personality traits (Standardized $\beta=$ $0.690, \mathrm{R}^{2}=0.476, \mathrm{p} \leq 0.05$ ), also it was observed that the five-factor personality traits had a statistically significant and negative effect on negative affect, and $9 \%$ of the decrease in negative affect could be explained by the five-factor personality traits (Standardized $\beta=-0.292, \mathrm{R}^{2}=0.085, \mathrm{p} \leq 0.05$ ).
\end{abstract}

Keywords: Personality structure, five factor personality theory, positive affect, negative affect, structural equation modeling

\footnotetext{
${ }^{1}$ Yozgat Bozok Üniversitesi, İktisadi ve İdari Bilimler Fakültesi, ftmttkk1@gmail.com

${ }^{2}$ Kırşehir Ahi Evran Üniversitesi, İktisadi ve İdari Bilimler Fakültesi, ffcetinkaya40@gmail.com
}

Atıf için (to cite): Korkmaz, F. ve Çetinkaya, F. F. (2021). Kişilik özelliklerinin pozitif ve negatif duygular üzerine etkisinin yapısal eşitlik modellemesiyle incelenmesi. Afyon Kocatepe Üniversitesi Sosyal Bilimler Dergisi, 23(3), 774-790. 
Paper Type: Research

\section{Giriş}

Son y1llarda neredeyse bütün örgütlerde insan faktörüne geçmişe nazaran daha fazla önem verilmektedir. İnsan faktörü bir örgütte başarı, etkinlik, verimlilik, rekabet üstünlüğü ve üretkenlik gibi konularla ilişkili olduğu için örgüt yönetimlerinin üzerinde daha çok çalıştığı bir durum haline gelmiştir. İş yaşamında başarının elde edilmesi ve bu başarının devam ettirilmesinde örgüt çalışanlarının rolü açık bir şekilde görülmektedir. Örgütler, kendilerine belirledikleri amaçlar çerçevesinde çalışanlarını da bu amaçlar etrafına toplayarak bir uyum sağlamaya çalışmaktadır. Dolayısıyla insan faktörünün bu denli önemli olduğu bir ortamda çalışanların kişilik özellikleri daha çok ön plana çıkmaktadır. Örgütte çalışanların uyum içerisinde çalışmaları için öncelikle kişilik özelliklerinin ve duygu durumlarının bilinmesi sağlıklı bir çalışma ortamı için gerekli koşulların başında gelmektedir.

Örgütlerde genel itibariyle her zaman kusursuz bir çalışma ortamının ve çalışanlar arasında işbirliğinin sağlanması mümkün olmamaktadır. Örgütlerin etkin ve verimli bir yapıya sahip olması, tüm çalışanların uyum içerisinde ve amaçlara ulaşılabilirlik seviyesinde olmasıyla gerçekleşir. Bu durumu bozan pek çok faktör olmakla birlikte çalışanların kişilik özellikleri ve duygu durumları bu faktörlerin en önemlileri arasında yer almaktadır. Örgütte çalışanların kişilik özellikleri ve duygu durumları örgütün bütününü etkileyebilecek bir potansiyele sahiptir. Ayrıca kişilik özellikleri ve duygu durumları son yıllarda gerek teori bağlamında sosyal bilimlerin birçok alanında araştırılmaya değer görülmekte gerekse de pratikte modern iş yaşamında gizli bir sorun olarak karşımıza çıkmaktadır. Buradan hareketle, bu çalışmada çalışanların kişilik özelliklerinin duygu durumları üzerindeki etkileri incelenmektedir.

\section{Kavramsal Çerçeve}

Çalışmanın bu kısmında kişilik kavramı ve beş faktör kişilik özellikleri ile pozitif ve negatif duygulara yönelik kavramsal çerçeve sunulmakta ve beş faktör kişilik özelliklerinin pozitif ve negatif duygulara etkisini açıklayan kuramsal temeller ve literatürde yer alan çalışmalar incelenerek araştırma modeli ve hipotezlerine yer verilmektedir.

\subsection{Kişilik Kavramı ve Beş Faktör Kişilik Özellikleri Kuramı}

Kişilik kavramı, bireylerin sosyal yaşamlarının bir parçası olarak yüzyıllardır ilgi çekmesine karşın kavramın bilimsel gelişimi, 1930 yıllarında kişilik psikolojisi alanının sosyal bilimin diğer alanlarından ayrılarak bilimsel bir disiplin haline gelmesiyle başlamıştır (Mc Adams, 1997, s. 4). Kişilik kavramını tanımlamadan önce kelimenin kökeni incelendiğinde Latince "persona" kavramından ortaya çıktı̆̆1 görülmektedir. "Persona" kavramı tiyatro oyuncularının girdikleri rollere göre kullandıkları maskelere verilen isim olup, bu kavramla kişilerin karakteristik ve bilişsel özellikleri ile farklılıkları belirtilmektedir (Atkinson vd., 2019, s. 421; Eroğlu, 2017, s. 203). Bir bireyi diğerlerinden ayıran fiziksel ve psikolojik özelliklerin tamamı şeklinde nitelendirilen kişilik kavramı, doğuştan gelen birtakım genetik yap1 faktörlerinin yanı sıra, yaşam içerisinde ortaya çıkan sosyo-kültürel unsurları, aile, sosyal yapı ve coğrafi faktörler gibi unsurları da kapsayan bir bütündür. Modern disiplinlerde çeşitli karşılıkları olan kişilik, bireylerin sahip oldukları bireysel özellikleri ile sosyal yeteneklerinin toplamını, bununla birlikte içinde bulundukları çevrenin etkisinde kalarak geliştirdikleri davranış yönelimlerini vurgulamak için kullanılmaktadır (Arslan ve Yener, 2015; Yener vd., 2018). Kişilik, davranışları yönlendirmede oldukça etkili olması bakımından davranış bilimcilerin ilgi odağında önemli bir yere sahiptir (Şimşek vd., 2014, s. 80).

Literatürde kişilik kavramı ile ilgili birçok tanımın yapıldığı görülmektedir. Özellikle farklı alanlarda kullanılan kavram Morgan'a (2011, s. 286) göre bireylerin başkalarının yanında gösterdiği davranış ve tutum iken; Ordun'a (2004, s. 48) göre bireylerin birbirlerinden farklı 
olarak sahip oldukları his ve bilişsel özelliklerinin bir bütünüdür. Bir diğer tanıma göre kişilik kavramı, bireylerin benzersiz karakter özelliklerine göre meydana gelen dinamik bir süreç olup, onların davranışlarını ve motivasyonunu etkilemektedir (Allport, 1961, s. 28 ve Ryckman, 1997, s. 5'den akt. Lau ve Shaffer, 1999, s. 225). Tommasel vd. (2015, s. 814) psikoloji teorilerinin, kişiliği davranışsal ve duygusal bir kombinasyon olarak tanımladığını ve kişiliğin bir süreç olduğunu aktarmaktadır. Buna göre kişilik, bireyin davranışlarını etkileyen ve diğer bireylere karşı tepkilerini belirleyen bir faktör ve aynı zamanda bireylerin içinde var olan potansiyel özelliklerini açığa çıkartması ve ortaya çıkan bu özellikleri yönetmesinden oluşan bir süreçtir. Kişiliğin amacında kendini bilmek, içsel olarak tanımak, yaşadığı topluma ve kültüre kabul ettirmek gibi özellikler de yatmaktadır (Tommasel vd., 2015, s. 814).

Kişilik kavramı ile ilgili literatürde yer alan farklı tanımlamalar genel olarak benzer özelliklerden söz etmektedir. Buradan hareketle kişiliğin, bireylerin sahip oldukları davranış biçimleri, ilgileri, ruhsal özellikleri, eğilimleri ve yetenekleri gibi özellikleriyle bütünleşmiş bir terim olduğunu, bireylerin hem iç hem de diş çevreleriyle geliştirdikleri ilişkileri şekillendirdiğini ve kendilerine özgü, diğer bireylerle aralarında fark yaratan özellikler bütünü olduğunu söylemek mümkündür. Bireylerin davranışlarını asli olarak yönlendiren etken kişiliktir. Bireye özgü ve ayırt edici olan, tutum ve davranışların nasıl şekilleneceğini belirleyen kişilik özelliklerinin yapılanmış ve tutarlı olması gerekmektedir. Bir başka ifadeyle, bireylerin sahip oldukları özellikler mekan ve zamana göre farklılaşmamalıdır (Cüceloğlu, 2002, s. 404; Norman, 1963, s. 575 ve Rogers, 2005, s. 1'den akt. Develioğlu ve Tekin, 2013, s. 17).

Kişiliğe ilişkin çeşitli tanımlar yapılmış olmasına rağmen kişiliğin nasıl oluştuğu ile ilgili net bir kuram ortaya çıkarılamamıştır. Bu duruma, bireylerin doğuştan sahip oldukları pek çok özellikleri ile daha sonradan kazandıkları özelliklerinin onların yapılarına yansımalarının farklılaşmasının sebep olduğunu söylemek mümkündür (Merdan, 2013, s. 142). Geçmişten günümüze, kişilik kavramının tanımlanması ve ölçülmesi ile ilgili farklı araştırmacılar farklı kuramlar geliştirmişlerdir. Bu kuramlar içerisinde, kişilik özelliklerini ölçmek amacıyla çeşitli araştırmalarda yaygın şekilde kullanılan kuramlardan biri de özellikler yaklaşımını temel edinen ve kişiliğin ölçülmesinde bireylerin hem kendilerini hem de diğer bireyleri tanımlamada kullandıkları sıfatlardan faydalanılan beş faktör kişilik özellikleri kuramıdır (Doğan, 2013, s. 57).

Paul Costa ve Robert McCrae'nin 1985 y1lında geliştirdikleri beş faktör kişilik özellikleri kuramı kişilik özelliklerinin tamamını kapsayan ve bu özelliklerin etraflıca açılanmasını sağlayan bir kuramdır. Bu bağlamda beş faktör kişilik özellikleri kuramını, evrensel ve eksiksiz olarak tüm kişilik özelliklerini gözleme dayandırılmış şekilde beş temel faktörde ele alıp sınıflandıran bir kişilik kuramı şeklinde tanımlamak mümkündür (Demirci vd., 2007, s. 21; McCrae ve Costa, 2006, s. 227). Bu beş temel faktör, sorumluluk, uyumluluk, duygusal denge, deneyime açıklık ve dişa dönüklük olarak ifade edilmektedir (Goldberg, 1992, s. 26). Sorumluluk faktöründe sistemli, azimli ve başarma yönelimli bir eğilim görülmektedir. Uyumlulukta; alçak gönüllü, iş birliğine inanan ve samimi anlayışlı bir durum söz konusudur. Duygusal dengede; rahat, özgüvenli, eleştiriye açık, strese toleranslı kişilik yapısı mevcuttur. Deneyime açıklıkta; yaratıcı, dışarıdaki görüşlere açık ve duyarlı davranışların varlığı belirtilmektedir. Dışa dönüklükte ise; sıcakkanlı, samimi, enerji ve neşe dolu, heyecana açık ve baskın karakter özellikleri görülmektedir. Bu sayılan özellikler faktör analizinde yüksek puanlara sahip iken; mesafeli, sakin, geleneksel, çekingen, dik başl1, inatçı ve plansız gibi karakter özellikleri düşük puan almıştır (McCrea ve Costa, 1991, s. 368).

Beş faktör kişilik özellikleri kuramının dayandığı temel varsayım, bireylerin göstermiş oldukları bireysel farklılıkların dünya üzerindeki tüm dillerde kodlanabileceği, konuşma diline sözcükler şeklinde yansıyabileceği ve bu sözcüklerden hareket ederek bireylerin kişilik yapılarını içerecek bir sınıflamanın yapılabileceğidir (Somer ve Goldberg, 1999). Beş faktör kişilik özellikleri kuramının birçok araştırmacı tarafından benimsenmesinin ve kişiliğe ilişkin araştırmalarda yaygın olarak kullanılmasının sebepleri arasında; kuramın deneysel ve boylamsal 
çalışmalara dayandırılması, ölçülen özelliklerin zaman geçse de devamlılığını koruyor olması, bazı biyolojik temellere sahip olması, farklı grup ve kültürlerde geçerliliğinin sınanmış olması ve psikometrik yönden hem kullanımı hem de değerlendirilmesinin kolay olmasını sıralamak mümkündür (Costa ve McCrae, 1992a, s. 653).

\subsection{Pozitif ve Negatif Duygular}

Duygu kavramı, "belirli bir nesne, olay veya bireylerin insanın iç dünyasında uyandırdığı izlenim" olarak tanımlanmaktadır (www.tdk.gov.tr, 2020). Oğuzkan'a (1981) göre duygu; belirli bir uyaran karşısında genelde değer ve güdülerle ilintili olarak meydana gelen, heyecandan zayıf olan bir uyarım biçimidir. Bir başka tanıma göre; içeriden veya dışarıdan uyaranlara karşı bir tepki olarak deneyimlenen çeşitli yaşantılardır (Pınar ve Kubilay Pınar, 2015, s. 347). Duygular bireylere, olaylara ya da objelere karş1 elde edilen tecrübeler sayesinde kazanılan ve bireyleri davranışta bulunmaya hazırlayan hisler bütünüdür (Weiss ve Cropanzano, 1996, s. 17).

Önceki yıllarda, duyguların sınıflandırılması ile ilgili yapılan çalışmalarda duygular tek boyut olarak ele alınırken, son yıllarda yapılan çalışmalarda ise duyguların pozitif ve negatif duygular olmak üzere birbirinden ayrı iki temel boyutta değerlendirildiği belirtilmektedir (Russell, 1980; Watson vd., 1984; Watson ve Telegen, 1985; Watson vd., 1988; Zevon ve Telegen, 1982). Pozitif duygu, bireylerin hayattan aldıklar1 aktif haz ve keyif olarak ifade edilirken; negatif duygu, bireylerin, stres, korku, kızgınlık, gerginlik, kaygı vb. hoş olmayan duygularının aktive olması şeklinde ifade edilmektedir (Watson vd., 1988). Duygu yapısının pozitif ve negatif duygular olarak ayrı ayrı incelenmesi lateralizasyon çalışmalarında da oldukça önem arz etmektedir. Lateralizasyon çalışmaları çerçevesinde, pozitif duyguların yaşanması ve iletilmesinden beynin sağ yarım küresi sorumlu tutulurken; negatif duyguların yaşanması ve iletilmesinden ise beynin sol yarım küresi sorumlu tutulmaktadır (Davidson, 1992). Bu bağlamda, duygu değerlendirmesi ve sınıflandırmasında, bu iki ayrı boyuta ilişkin ayrı ayrı bilgi edinilmesinin büyük önem taşıdığı gözlenmektedir (Gençöz, 2000, s. 20). Ayrıca yapılan çalışmalar incelendiğinde, duygu kavramıyla ilişkili olarak duygusallık/duygulanım kavramlarının birbirleri yerine kullanılabilen kavramlar olduğu görülmektedir. Bu sebeple pozitif ve negatif duygular ile pozitif ve negatif duygusallık/duygulanım kavramlarını birbirlerinin yerine kullanmak mümkün olabilmektedir (Pınar ve Kubilay Pınar, 2015, s. 347).

Pozitif duygular, bireyin duygularından elde ettiği enerjiyi ihtiyaçlarında kullanmak için aktif hale getirdiği zaman ortaya çıkmaktadır. Pozitif duygular keyif hissi veren duygulardır. Pozitif duygulara sevinç, ilgi, güven, kararlılık ve istikrar gibi durumlar örnek verilebilir (Diener vd., 1997). Pozitif duyguların birçok işlevi bulunmaktadır. Öncelikle pozitif duygular mantık yürütmeyi ve öğrenmeyi kolaylaştırmaktadır. Ayrıca bireylerin başkaları ile olan ilişkilerini kolaylaştırarak bireylerin gelişimlerini artırmaktadır (Collins ve Gunner, 1990). Pozitif duygular, bireylerin yaratıcı sorun çözme becerilerini geliştirmekte ve onların olumsuz konularla baş edebilmelerini sağlamaktadır. Bireylerin pozitif duygular geliş̧irmeleri ve bu duygularla sürdürülebilir bir yaşam oluşturabilmeleri, onların daha dayanıklı olmalarını sağlayarak negatif duygulara maruz kalmalarını önleyebilmektedir (Fredrickson, 2001). Ayrıca pozitif duyguların; zeka, karar verme yeteneği, yaratıcılı̆̆ geliştirme, yeniliklere açık ve uyumlu olma ve açı fikirli olma gibi özellikler üzerinde de önemli rollere sahip olduğu görülmektedir (Lyubomirsky vd., 2005). Pozitif duygulara ilişkin yapılan çalışmalarda, pozitif duygu düzeyleri yüksek olan bireylerin ilgili, neşeli, zihinsel açıdan dinç, azimli ve coşkulu olma gibi duygulara sahip oldukları, pozitif duygu düzeyleri düşük olan bireylerin ise bitkinlik ve uyuşukluk gibi negatif duygular taşıdıkları gözlenmektedir (Clark ve Watson, 1991).

Duygu sinıflandırmasında ikinci temel boyut olan negatif duygu ise, kin, nefret, korku, kıskançlık vb. bozucu duyguları kapsayan bir kavramdır. Örgüt ortamında ve sosyal yaşamda genellikle görülen çatışmalar, stres, tükenmişlik, depresyon vb. konuların temelinde negatif duyguların yoğunluğu yatmaktadır. Bu olumsuz duygular bireyleri etkisi altına almakta ve örgüt 
yaşamını kötü yönde etkilemektedir (Töremen ve Çankaya, 2008, s. 39). Watson vd.'nin (1988) yapmış oldukları pozitif ve negatif duygu ölçek geliştirme çalışmasında pozitif ve negatif duygular on maddelik bir kategorizasyona tabi tutulmuştur. Bu uygulamada negatif duygu boyutunda "ürkmüş, suçlu, mutsuz, sıkıntıl1, düşmancıl, asabi, korkmuş, tedirgin, sinirli ve utanmış" maddeleri yer almaktadır (Watson vd., 1988). Negatif duygular olaylara olumsuz pencereden bakışı açıklamaktadır. Negatif duygu bireyleri kötü hissettiren nefret, öfke ve kızgınlık gibi duyguları ifade eder. Negatif duygusu baskın olan bireyler sosyal hayatlarında gerginlik yaşayabilir, suçluluk, endişe ve üzüntü gibi duygulara kapılabilir. Bu durum örgüt yaşamında da paralel şekilde devam etmektedir. Eğer bir örgütteki bireylerin negatif duygu durumları yüksek ise o örgütte bireyler arası anlaşmazlıklar ve sorunlar daha çok yaşanmakta ve bu durum örgüte ciddi zararlar vermektedir (Can vd., 2011, s. 167-168).

Pozitif ve negatif duygu kavramlarıla ilgili yurt içinde ve yurtdışında yapılan çalışmalarda araştırmaların çoğunluğunun psikoloji alanında olduğu görülmektedir. Son yıllarda bu kavramların örgütsel alanda da sıkça kullanıldığı göze çarpmaktadır. Psikolojide yapılan çalışmalarda pozitif duygunun dişa dönük kişilikle, negatif duygunun ise nevrotik kişilikle ilintili olduğu ortaya konulmuştur (Gençöz, 2000, s. 20). Konunun iş örgütleriyle bağlantısı göz önünde alındığında ise literatürde yer alan çalışmalarda yüksek düzeyde negatif duygulara sahip olan bireylerin daha karamsar bir ruh haline sahip oldukları ve hem genel yaşam tatmin hem de iş tatminlerinin daha düşük düzeylerde olduğu, pozitif duygu düzeyleri yüksek olan bireylerin ise hem genel yaşam tatmin hem de iş tatminlerinin daha yüksek düzeylerde olduğu ifade edilmektedir (Özdemir, 2015, s. 51).

\subsection{Beş Faktör Kişilik Özellikleri ile Pozitif ve Negatif Duygular Arasındaki İlişki}

Beş faktör kişilik özellikleri kuramı çerçevesinde; sorumluluğu yüksek olan bireyler, organize olabilme yetenekleri iyi, dikkatli davranan, disipline önem veren, liderlik vasıfları taşıyan, planlı ve zamanlı hareket eden, çalışkan, düzenli, kararlı, başarı odaklı, azimli, hırslı ve işlerine bağlıdır. Bu bireyler aynı zamanda yüksek iş motivasyonuna sahiptirler ve yaptıkları işten yüksek düzeyde doyum sağlarlar. Sorumluluğu düşük olan bireyler ise; özensizce davranma, dikkatlerini toplayamama, üşengeç, tembel, ihmalkar, düzensiz, güven vermeyen, amaçsız yaşama ve işten kaçma eğilimi gösteren özelliklere sahiptir. Sorumluluk duygusu yüksek bireyler, sorumluluk duygusu düşük olan bireylere göre tepkilerinde akılcı ve pozitif olmaya daha eğilimlidirler ve kurallara uyma noktasında daha tutarlı davranmaktadırlar (McCrae ve Costa, 1987, 2003; Witt vd., 2002).

Uyumluluğu yüksek olan bireyler, yumuşak huylu, esnek, destekleyici, hoşgörülü, nazik, saygılı, sıcakkanlı ve samimi duruşlarıyla rekabetten ziyade işbirliğine ve güvene dayalı ilişkiler kurarlar. Uyumluluğu düşük olan bireyler ise; acımasız davranışları olan, şüphe uyandıran, cimri, her şeye eleştirel yaklaşan, empati yeteneğinden yoksun, bencil, çabuk öfkelenen, düşmanlık, kin, nefret ve kıskançlık gibi negatif duygular besleyen bireylerdir (Burger, 2006; Digman, 1990; McCrae ve Costa, 1987; McCrae ve Costa, 2003; McCrea ve John, 1992; Sneed, 2002; Zellars vd., 2000). Yapılan çalışmalara göre uyumluluk faktörü ile bireylerin ahlaki değerleri arasında kuvvetli bir ilişki bulunmaktadır (Somer, 1998).

Duygusal denge düzeyi yüksek olan bireyler; rahat davranışlar sergileme, stresli zamanlarda sakinliğini koruyabilme, öfke kontrolü yapabilme, zor koşullara karşı dayanıklı olma, kendileriyle barışık olma, öz güvenleri yüksek ve pozitif duygular yaşamaya yatkın olma gibi özelliklerle ifade edilmektedir (Benet-Martinez ve John, 1998; Costa ve McCrae, 1992b; Costa ve McCrae, 1995; McCrae ve Costa, 2003; Somer vd., 2002). Duygusal denge düzeyi düşük olan yani nevrotik bireyler ise; negatif duygusallık, anksiyete, umutsuzluk, üzüntü, depresyon, stres, suçluluk hissi ve takıntı gibi rahatsızlıkları sebebiyle uzun süreçli negatif duygular yaşama eğilimi göstermekte ve bu bireyler yapıları doğası farklı davranış bozuklukları sergileyebilmektedir. Ayrıca bu bireylerde düşük öz saygı, gerçeği yansıtmayan mükemmeliyetçilik inancı, karamsarlık ve negatif duygu durumları görülme olasıllığı oldukça 
yüksektir (Cooper vd., 2013; McCrae ve Costa, 1987; Somer vd., 2002). Yapılan çalışmalar incelendiğinde, nevrotikliğin negatif duyguları anlamlı ve yüksek düzeyde yordadığ görülmektedir (Fujita, 1991; Lucas ve Fujita, 2000).

Deneyime açılık duygusu yüksek olan bireyler, entelektüel, zeki, yaratıcılıkları gelişmiş, araştırmacı, yenilikçi, macerayı seven, geniş hayal gücü olan, özgür ruhlu ve ileriyi görebilen bireylerdir. Ayrıca bu bireyler, gelenek dişı ve özgür düşüncelere sahiptirler ve geleneğe bağlı değerleri sorgulama eğilimi göstermektedirler (Burger, 2006; Costa vd., 1986; McCrea ve Costa, 2003; Somer, 1998; Thoms vd., 1996). Deneyime açıklık duygusu düşük olan bireyler ise; daha gerçekçi, yaratıcılık yönleri zayıf, yeniliklere kapalı, gelenekçi ve alışılmışın dışına çıkmayan muhafazakâr bir yaklaşım benimseme ve tutucu olma gibi özelliklerle bilinmektedirler (Burger, 2006; McCrae ve Costa, 2003).

Son olarak, dişadönüklük duygusu yüksek olan bireyler, sosyal ilişkileri kuvvetli, enerji dolu, sıcakkanlı, neşeli, iyimser, atılgan davranışlar sergileme ve girişkenlik gibi özelliklere sahiptirler (Burger, 2006; McCrae ve Costa, 1987). Dişa dönüklük duygusu düşük olan yani içe dönük bireyler ise, sessiz, kendi halinde, içine kapanık, sınırlı sayıda arkadaşa sahip olan bireylerdir ve çoğunlukla yakın arkadaşlarıyla vakit geçirme haricinde yalnız kalmayı tercih etmektedirler (Eysenck ve Eysenck, 1969). Dışadönükler, sahip oldukları özellikler sayesinde pozitif duygular gösterebilmekte, bu bağlamda sorunları pozitif yönleriyle tekrar değerlendirmeyi tercih etmekte ve iş ortamı ve çalışma çevrelerini daha pozitif algılamaktadırlar (Alarcon vd., 2009; Bouchard vd., 2004; DeLongis ve Holtzman, 2005; McCrae ve John, 1992; Watson ve Clark, 1997). Araştırmacılara göre, dışadönük bireyler içedönüklere nazaran, daha güçlü pozitif etkilere, daha fazla pozitif olay beklentilerine, daha güçlü tepki düzeylerine ve daha fazla enerjiye sahip bireylerdir. Bu sayede dişadönükler çevrelerine daha fazla pozitif enerji yayabilmekte ve daha fazla pozitif ruh haline sahip olabilmektedirler (Wayne vd., 2004). Ayrıca, yapılan çalışmalar incelendiğinde, dışa dönük kişilik özelliği taşıyan bireylerin pozitif duygular yaşamaya daha eğilimli oldukları ve pozitif duyguları anlamlı ve yüksek düzeyde yordadığ

Pozitif duygular ile dışadönüklük arasındaki ilişkiyi açıklayan ve doğrulayan araştırmalar aynı zamanda beş faktör kişilik özellikleri kuramının kapsamının netleşmesine de katkı sağlamaktadır. Araştırmalardan elde edilen bulgulara göre, neşeli, istekli ve arkadaş canlısı gibi enerjik, pozitif duyguların ağırlıklı olarak dışadönüklük faktörüne ve ikincil olarak uyumluluk faktörüne yüklendikleri; cömert ve sıcakkanlı gibi daha samimi, 1lımlı ve pozitif duyguların ise, ağırlıklı olarak uyumluluk faktörüne ve ikincil olarak dışadönüklük faktörüne yüklendikleri ifade edilmektedir. Bununla birlikte, düşüncesizlik, tepkisizlik ve dikkatsizlik gibi özelliklerin ise sorumluluk faktörüne negatif yönlü yüklendikleri ifade edilmektedir (Johnson ve Ostendorf, 1993).

Beş faktör kişilik özellikleri kuramının zamanla bilimsel çalışmalarda daha fazla yer edinmeye başlaması, özellikle çalışanların kişilik özelliklerinin iş ortamındaki ve çalışma hayatındaki davranışlarıyla olan ilişkilerini ve kişilik özelliklerinin hangi davranış tarzlarını daha fazla etkilediğini açıklamaya yönelik çalışmaların yaygınlaşmasını sağlamıştır. Bu bağlamda bu kuramın, yönetim ve organizasyon, örgütsel psikoloji ve örgütsel davranış alanlarında da çok yaygın olarak kullanıldığını söylemek mümkündür (Sığrı ve Gürbüz, 2011). Örneğin, literatürdeki çalışmalar incelendiğinde, kariyer yönetimi, kariyer seçimi, liderlik tarzları, örgütsel değişim, psikolojik dayanıklılık, örgütlerde insan enerjisi, örgütsel vatandaşlık davranışı, örgütsel adalet, motivasyon, kariyer başarısı, çatışma yönetimi, akademik güdülenme, yaşam doyumu, örgütsel erdem, iş performansı, akademik başarı, duygusal zeka ve iş tatmini (Abu Elanain, 2007; Basım vd., 2009; Bayram vd., 2019; Bernerth vd., 2007; Bitlisli vd., 2013; Caldwell ve Burger, 1998; Çetin vd., 2015; Eggers, 2000; Erkuş ve Tabak, 2009; Gökdeniz ve Merdan, 2011; Guthrie vd., 1998; Hirschfeld vd., 2008; Judge vd., 1999; McCormack ve Mellor, 2002; Leung ve Bozionelos, 2004; Lim ve Ployhart, 2004; Lounsbury vd., 1999; Shi vd., 2009; Sığr1 ve Gürbüz, 2011; Sudak ve Zehir, 2013; Sung ve Choi, 2009; Vakola vd., 2004) 
ile kişilik arasındaki ilişkilerin tespit edilmesinde beş faktör kişilik özellikleri kuramının yaygın şekilde kullanıldığı görülmektedir. Bununla birlikte, daha önce yapılmış çalışmalar incelendiğinde, çalışanların beş faktör kişilik özelliklerinin, pozitif ve negatif duygular sergileme potansiyelleri üzerinde yordayıcı bir etki yaptığı (Fujita, 1991; Lucas ve Fujita, 2000) ve beş faktör kişilik özelikleri ile pozitif duygular arasında anlamlı ve pozitif yönlü ilişkilerin olduğu, beş faktör kişilik özelikleri ile negatif duygular arasında ise anlamlı ve negatif yönlü ilişkilerin olduğu gözlenmektedir (Bacanlı vd., 2009; Baş Atik, 2018; Doğan, 2013; Harmanc1, 2018; Işsk ve Üzbe, 2015; Paulson ve Leuty, 2016; Ünsal ve Türetgen, 2013; Watson ve Clark, 1992, 1997).

Kuramsal altyapı ve literatür 1şığında oluşturulan araştırma modeli ve hipotezleri aşağıdaki gibidir;

Şekil 1. Araştırmanın şekilsel modeli

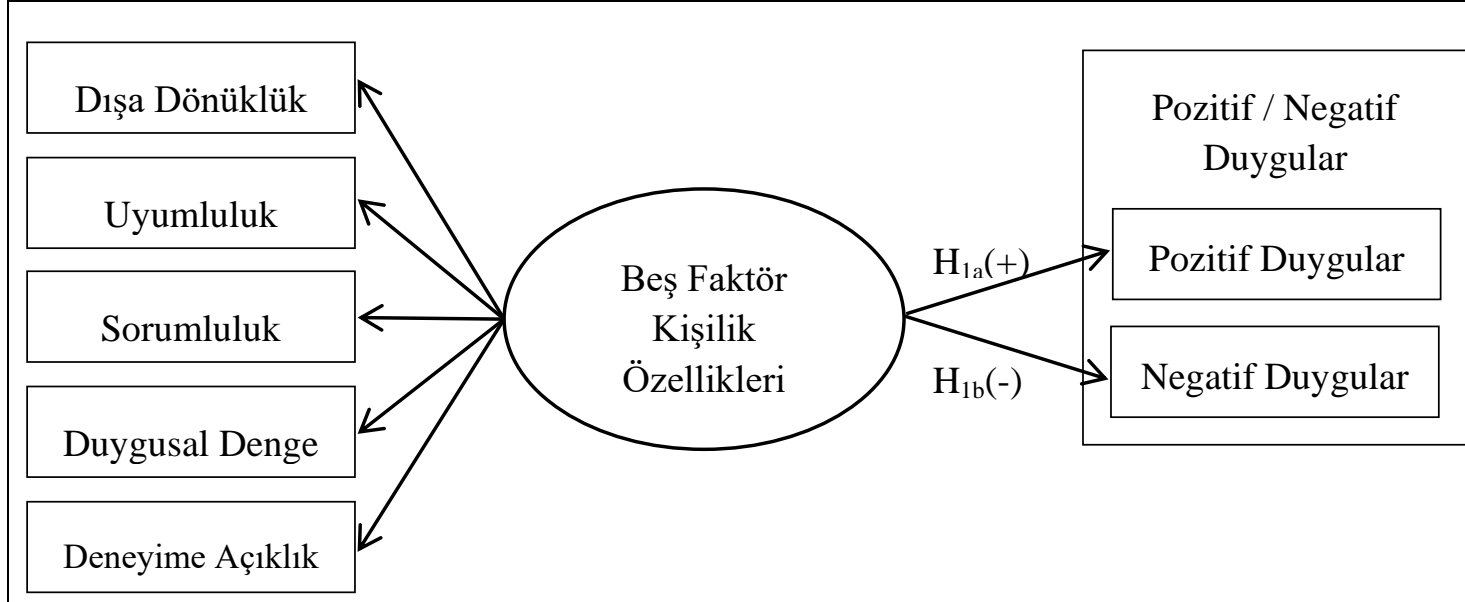

$\mathbf{H}_{1 \mathbf{a}}$ : Beş faktör kişilik özelliklerinin pozitif duygular üzerinde istatistiksel olarak anlamlı ve pozitif yönlü etkisi vardır.

$\mathbf{H}_{1 \mathbf{b}}$ : Beş faktör kişilik özelliklerinin negatif duygular üzerinde istatistiksel olarak anlamlı ve negatif yönlü etkisi vardır.

\section{Yöntem}

Bu kısımda araştırmanın evren ve örneklemi, veri toplama araçları, analiz yöntemi ve geçerlik ve güvenirlik sonuçlarına ilişkin bilgiler sunulmaktadır. Araştırma için Kırşehir Ahi Evran Üniversitesi, Sosyal ve Beşeri Bilimler Bilimsel Araştırma ve Yayın Etik Kurulu'nun 01/07/2020 tarih ve 2020/2 karar sayısı ile izin alınmıştır.

\subsection{Araştırmanın Evren ve Örneklemi}

Araştırma evrenini 2020 verilerine göre Kırşehir ilinde faaliyet gösteren 50 ve üzeri çalışana sahip özel sektör kuruluşlarının 8126 çalışanı, örneklemini ise bu evren kapsamında ulaşılan 463 çalışan oluşturmaktadır. Araştırmada zaman, maliyet ve ulaşım zorlukları nedeniyle evren sayısının tümüne ulaşmanın mümkün görünmemesinden dolayı olasılığa dayalı olmayan örnekleme yöntemlerinden olan kolayda örnekleme yönteminden yararlanılmıştır. Örneklem sayısının hesaplanması amaciyla ise Yamane (2001) tarafından geliştirilen örneklem sayıs1 hesaplama formülü kullanılmıştır. Buna göre araştırma evreni 8126 iken \%95 güven aralığında ulaşılması gereken örneklem sayısının 367 olması gerektiği tespit edilmiştir (Yamane, 2001: 116-117). Buradan hareketle 463 örneklemden toplanan verilerin, veri analizi için oldukça yeterli düzeyde olduğu görülmektedir. Araştırma verileri 02/07/2020-01/09/2020 tarihleri arasında, yüz yüze anket yöntemi ile Google forms uygulaması üzerinden online veri girişi yoluyla elde edilmiştir. Örnekleme ilişkin demografik dağılımlar Tablo 1'de yer almaktadır. 
Tablo 1. Örnekleme ilişkin demografik dağımlar

\begin{tabular}{|c|c|c|c|c|c|}
\hline Değişkenler & Frekans (463) & $\%(100.0)$ & Değişkenler & Frekans (463) & $\%(100.0)$ \\
\hline Cinsiyet & & & Yaş & & \\
\hline Kadın & 168 & 36.3 & $18-25$ & 130 & 28.1 \\
\hline Erkek & 295 & 63.7 & $26-30$ & 135 & 29.2 \\
\hline Medeni Durum & & & $31-44$ & 145 & 31.3 \\
\hline Evli & 193 & 41.7 & $45-64$ & 53 & 11.4 \\
\hline Bekâr & 270 & 58.3 & Çalışma Süresi & & \\
\hline Eğitim Durumu & & & $1-5$ y1l & 286 & 61.8 \\
\hline İlköğretim & 39 & 8.4 & 6-10 y1l & 81 & 17.5 \\
\hline Lise & 120 & 25.9 & $11-15$ y1l & 35 & 7.6 \\
\hline Ön Lisans & 101 & 21.8 & $16-20 \mathrm{y} 1 \mathrm{l}$ & 27 & 5.8 \\
\hline Lisans & 180 & 38.9 & $21-25$ y1l & 13 & 2.8 \\
\hline Yüksek Lisans & 17 & 3.7 & 26 yıl ve üzeri & 21 & 4.5 \\
\hline Doktora & 6 & 1.3 & & & \\
\hline
\end{tabular}

Tablo 1'e göre, 463 kat1lımcının 295'i (\%63.7) erkeklerden, 168'i (\%36.3) kadınlardan oluşurken, 193'ünün (\%41.7) evli, 270'inin (\%58.3) bekâr olduğu görülmektedir. Yaş gruplarına göre ise; katılımcıların büyük çoğunluğunun genç ve orta yaş grubunda dağılım gösterdiği gözlenmektedir. Eğitim durumu açısından incelendiğinde, katılımcıların büyük çoğunluğunun lise, ön lisans ve lisans düzeyinde eğitim seviyesine sahip oldukları görülmektedir. Son olarak çalışma süresi açısından ise, katılımcı sayılarının, 1-5 yıl arasında 286 (\%61.8), 6-10 y1l arasında 81 (\%17.5), 11-15 y1l arasinda 35 (\%7.6), 16-20 y1l arasinda 27 (\%5.8), 21-25 yıl arasında $13(\% 2.8)$ ve 26 yıl üzerinde ise $21(\% 4.5)$ olduğu gözlenmekte ve katılımcıların yarısından fazlasının 1-5 yıl arasında dağıldığı dikkat çekmektedir.

\subsection{Veri Toplama Araçları ve Analiz Yöntemi}

Araştırmada analiz yöntemi olarak nicel veri analizi kullanılmıştır. Kullanılan anket formu, demografik sorular ile on maddeli kişilik ölçeği ve pozitif ve negatif duygular ölçeğinden oluşmaktadır. Çalışanların beş faktör kişilik özelliklerini ölçmek için Gosling vd. (2003) tarafından geliştirilen ve Atak (2013) tarafından Türk kültürüne uyarlanan On Maddeli Kişilik Ölçeği (OMKÖ) kullanılmıştır. Pozitif ve negatif duyguları ölçmek için ise Watson vd.'nin (1988) geliştirdiği ve Gençöz'ün (2000) Türk kültürüne uyarladığg Pozitif ve Negatif Duygu Ölçeği kullanılmıştır. On Maddeli Kişilik Ölçeği, “Dışa Dönüklük”, “Uyumluluk”, "Sorumluluk", "Duygusal Denge" ve "Deneyime Açıklık" olmak üzere 5 boyut ve 10 maddeden oluşmaktadır. Pozitif ve Negatif Duygu Ölçeği ise, "Pozitif Duygular" ve "Negatif Duygular' olmak üzere 2 boyut ve toplamda 20 maddeden oluşmaktadır.

Araştırma modeli için yapısal eşitlik modellemesi tercih edilmiştir. Araştırma modelindeki değişkenler arasındaki ilişki, SPSS 22.0 ve AMOS 24 paket programları ile çözülerek ilgili bulgular değerlendirilmiştir. Araştırma kapsamında öncelikle veri toplama araçlarının geçerlik testi için doğrulayıcı faktör analizi uygulanmış, ardından güvenirlik analizi için ise Cronbach's alpha değerleri incelenmiştir. Bununla birlikte demografik dağılımlar için tanımlayıcı istatistiki analizler kullanılmıştır. Daha sonra değişkenler arasındaki ilişkileri tespit etmek için korelasyon analizi uygulanmış, beş faktör kişilik özelliklerinin pozitif ve negatif duygular üzerindeki etkisini tespit etmek için ise yapısal eşitlik modellemesi ile olası etkiler test edilmiştir.

\section{3. Ölçeklerin Geçerlik ve Güvenirlikleri}

Veri toplama aracı olarak kullanılan on maddeli kişilik ölçeği ve pozitif ve negatif duygu ölçeğine ait yap1 geçerliklerini doğrulamak için kurulan ölçüm modelleri doğrulayıcı faktör analiziyle test edilmiş ve ayrıca güvenirlik değerleri tespit edilmiştir. Doğrulayıcı faktör analizi esnasında pozitif ve negatif duygular ölçeğinin ise 3. 4. ve 9. maddeleri çok fazla 
modifikasyon yüklenerek yapı geçerliklerini bozdukları için ölçek dışına çıkarılmıştır. Analizler sonucunda oluşan geçerlik (uyum indeks değerleri) ve güvenirlik değerleri Tablo 2'de sunulmaktadır.

Tablo 2. Ölçeklerin geçerlik ve güvenirlik sonuçları

\begin{tabular}{lccccccc}
\hline Değişkenler & $\begin{array}{c}\chi^{2 / d f} \\
\leq 5\end{array}$ & $\begin{array}{c}\text { GFI } \\
\geq 0.85\end{array}$ & $\begin{array}{c}\text { CFI } \\
\geq 0.90\end{array}$ & $\begin{array}{c}\text { RMSEA } \\
\leq 0.08\end{array}$ & $\begin{array}{c}\text { Boyut } \\
\text { Sayıs }\end{array}$ & $\begin{array}{c}\text { Madde } \\
\text { Sayı1 } 1\end{array}$ & $\begin{array}{c}\text { Cronbach's } \\
\text { Alpha }\end{array}$ \\
\hline $\begin{array}{l}\text { Beş Faktör Kişilik } \\
\text { Özellikleri }\end{array}$ & 1.812 & 0.978 & 0.959 & 0.042 & 5 boyut & $\begin{array}{c}10 \\
\text { madde }\end{array}$ & 0.729 \\
\hline $\begin{array}{l}\text { Pozitif ve Negatif } \\
\text { Duygular }\end{array}$ & 2.390 & 0.933 & 0.906 & 0.055 & 2 boyut & $\begin{array}{c}17 \\
\text { madde }\end{array}$ & $0.794 / 0.763$ \\
\hline
\end{tabular}

Tablo 2 incelendiğinde, on maddeli kişilik ölçeği ve pozitif ve negatif duygular ölçeğine ait geçerlik analizi sonuçlarının her iki ölçek için de kabul edilebilir sınırlarda olduğu gözlenmektedir. Uygulanan güvenirlik analizine göre ise, her iki ölçeğin de yeterli düzeyde güvenilir olduğu sonucuna ulaşılmıştır.

\section{Bulgular}

Araştırmanın bu kısmında, araştırma modeli çerçevesinde yapılan veri analizleri sonucunda elde edilen bulgu ve sonuçlara yer verilmektedir.

\subsection{Değișkenler Arasındaki İlișki}

Bağımsız değişken olan beş faktör kişilik özellikleri ile bağımlı değişken olan pozitif ve negatif duygular arasındaki ilişkiyi tespit etmek amacıyla yapılan korelasyon analizi sonuçları Tablo 3'de görülmektedir.

Tablo 3. Değişkenler arasındaki ilişki düzeyi ve yönü

\begin{tabular}{|c|c|c|c|c|}
\hline \multicolumn{5}{|c|}{ Korelasyon } \\
\hline & & $\begin{array}{l}\text { Beş Faktör Kişilik } \\
\text { Özelikleri }\end{array}$ & $\begin{array}{c}\text { Pozitif } \\
\text { Duygular }\end{array}$ & $\begin{array}{c}\text { Negatif } \\
\text { Duygular }\end{array}$ \\
\hline \multirow{3}{*}{$\begin{array}{c}\text { Beş Faktör } \\
\text { Kişilik } \\
\text { Özelikleri }\end{array}$} & Pearson Korelasyon & 1 & $0.514^{* *}$ & $-0.158^{* *}$ \\
\hline & Sig. (2-tailed) & & .000 & .001 \\
\hline & $\mathrm{N}$ & 463 & 463 & 463 \\
\hline
\end{tabular}

Tablo 3'e göre, \%1 anlamlılık düzeyinde beş faktör kişilik özelliklerinin pozitif duygular ile arasında orta düzeyde anlamlı olumlu ilişki $(\mathrm{R}=0.514)$, beş faktör kişilik özelliklerinin negatif duygular ile arasında ise düşük düzeyde anlamlı olumsuz ilişki $(\mathrm{R}=-0.158)$ gözlenmiştir. Buradan yola çıkarak, bağımsız değişkenin bağımlı değişken üzerindeki etkisini test etmek için yapısal eşitlik modellemesiyle analiz yapmanın uygun olduğunu ifade etmek mümkündür.

\subsection{Yapısal Eşitlik Modeli}

Araştırma modeli kapsamında, beş faktör kişilik özelliklerinin pozitif ve negatif duygular üzerindeki etkisini $(\mathrm{OMKÖ} \rightarrow \mathrm{PD}, \mathrm{OMKÖ} \rightarrow \mathrm{ND})$ gösteren yapısal eşitlik modeli Şekil 2'deki gibidir. 


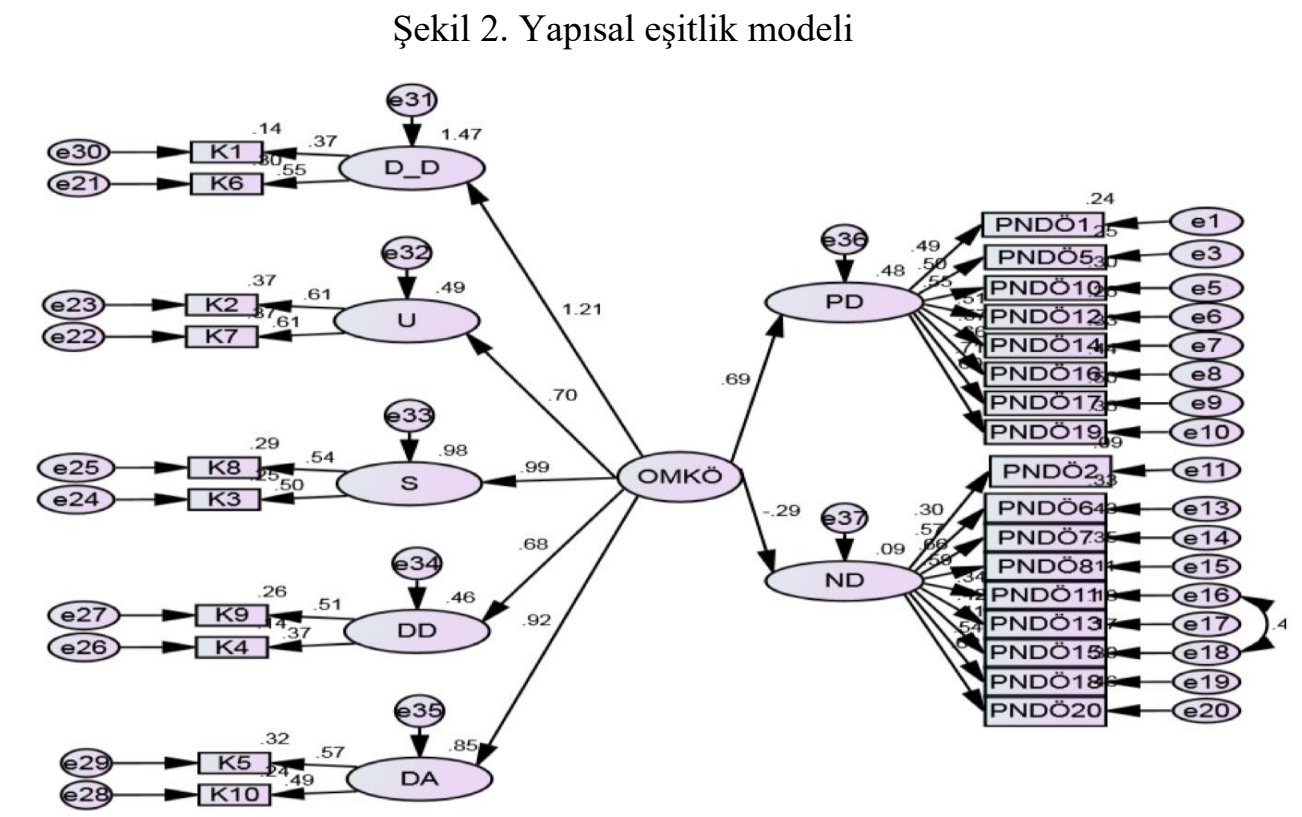

Beş faktör kişilik özelliklerinin pozitif ve negatif duygular üzerindeki etkisini test etmek için kurulan yapısal eşitlik modellemesinde ortaya çıkan değerler ise Tablo 4'de sunulmaktadır.

Tablo 4. Değişkenler arası etkiye ilişkin yapısal eşitlik modellemesi değerleri

\begin{tabular}{llllll}
\hline Değişkenler & Standardize $\beta$ & Std. Hata & C.R & $\mathrm{p}$ & $\mathrm{R}^{2}$ \\
\hline $\begin{array}{l}\text { Beş Faktör Kişilik Özellikleri - } \\
\text { Pozitif Duygular }\end{array}$ & 0.690 & 0.064 & 7.615 & 0.00 & 0.476 \\
\hline $\begin{array}{l}\text { Beş Faktör Kişilik Özellikleri - } \\
\text { Negatif Duygular }\end{array}$ & -0.292 & 0.034 & -3.782 & 0.00 & 0.085 \\
\hline
\end{tabular}

Tablo 4'e bakıldığında, beş faktör kişilik özelliklerinin pozitif ve negatif duygular üzerindeki etkisini gösteren yapısal eşitlik modellemesine göre elde edilen bulgular kapsamında, beş faktör kişilik özelliklerinin pozitif duygular üzerinde istatistiksel açıdan anlamlı ve olumlu yönde yüksek düzeyde etkisinin olduğu, pozitif duyguların \%48'inin beş faktör kişilik özellikleri ile açıklanabileceği (Standardize $\beta=0.690, \mathrm{R}^{2}=0.476, \mathrm{p} \leq 0.05$ ), öte yandan beş faktör kişilik özelliklerinin negatif duygular üzerinde ise istatistiksel açıdan anlamlı ve negatif yönde düşük düzeyde etkisinin olduğu, negatif duygulardaki azalışın \%9'unun beş faktör kişilik özellikleri ile açıklanabileceği (Standardize $\beta=-0.292, \mathrm{R}^{2}=0.085, \mathrm{p} \leq 0.05$ ) tespit edilmiştir. $\mathrm{Bu}$ bağlamda araştırma modelini ve hipotezleri test etmek için oluşturulan yapısal eşitlik modellemesinin doğrulandığını söylemek mümkündür.

\section{Sonuç, Tartışma ve Öneriler}

$\mathrm{Bu}$ çalışmada, çalışanların sahip oldukları beş faktör kişilik özelliklerinin onların pozitif ve negatif duyguları üzerindeki etkisi ortaya çıkarılmıştır. Araştırmanın örneklemi Kırşehir ilindeki 463 özel sektör çalışanından oluşmaktadır. Araştırma kapsamında ilk olarak veri toplama araçlarının geçerlik ve güvenirlikleri analiz edilmiş ve bu araçların yüksek düzeyde geçerli ve güvenilir oldukları tespit edilmiştir. Daha sonra korelasyon analizi ve ardından yapısal eşitlik modeli kullanılarak değişkenlerin birbiri üzerindeki etkisine yönelik araştırma bulguları değerlendirilmiştir. Beş faktör kişilik özellikleri kuramı çerçevesinde, çalışanların beş faktör kişilik özelliklerini oluşturan sorumluluk, dişa dönüklük, duygusal denge, uyumluluk ve deneyime açıklık düzeylerinin onların pozitif duygu düzeylerini arttırdığını ve negatif duygularını azalttı̆̆ını, dolayısıyla, literatür ve kuramsal alt yapı 1şı̆̆ında kurulan araştırma modeli ve hipotezlerin doğrulandığını ifade etmek mümkündür. Literatür incelendiğinde, bu 
araştırma sonuçlarını destekleyen, beş faktör kişilik özelliklerinin pozitif ve negatif duyguların bir belirleyeni olduğunu açıklayan, beş faktör kişilik özellikleri ile pozitif duygular arasında güçlü pozitif ilişkiler olduğunu, beş faktör kişilik özellikleri ile negatif duygular arasında ise negatif yönlü ilişkiler olduğunu ortaya çıkaran benzer araştırmaların yapıldığ 1 görülmüştür (Bacanlı vd., 2009; Baş Atik, 2018; Doğan, 2013; Harmanc1, 2018; Işık ve Üzbe, 2015; Fujita, 1991; Keleş, 2019; Lucas ve Fujita, 2000; Paulson ve Leuty, 2016; Ünsal ve Türetgen, 2013; Watson ve Clark, 1992, 1997).

Bir örgütte başarı, etkinlik, verimlilik, rekabet üstünlüğü ve üretkenlik gibi konularla ilişkili olan en temel faktör insan faktörüdür. Dolayısıyla, günümüzde hemen hemen bütün örgütlerde insan faktörüne eskiye göre çok daha fazla önem verilmekte ve örgüt yönetimleri insan faktörü üzerinde daha çok yoğunlaşmak durumundadır. Örgütte çalışanların uyum içerisinde çalışmaları için öncelikle kişilik özelliklerinin ve duygu durumlarının bilinmesi sağlıklı bir çalışma ortamı ve örgüt iklimi için gerekli koşulların başında gelmektedir. Gerek literatürde yer alan çalışmalara gerekse de iş dünyasındaki gelişmelere bakıldığında, çalışma hayatında, amaç ve hedeflere başarılı bir şekilde ulaşılarak etkinlik ve performansın arttırılması ve bu başarının sürdürülebilmesi için örgüt çalışanlarının rolü son derece önem arz etmektedir. $\mathrm{Bu}$ bağlamda bu çalışmadan elde edilen sonuçlar, çalışanlar yönünden değerlendirildiğinde, çalışma hayatında negatif duygulardan uzaklaşarak, pozitif duygulara yoğunlaşmak ve böylece hem genel ruh sağlığını korumak hem de daha pozitif etkileşimlerde bulunarak performans ve verimliği arttırmak amaciyla beş faktör kişilik özelliklerinden sorumluluk, dışa dönüklük, duygusal denge, uyumluluk ve deneyime açıklık kişilik özelliklerine yön verecek eğitimler alarak çalışanlar kendilerini iyi bir şekilde geliştirmeli ve yönetebilmelidir. Bu sonuçlar örgütler açısından değerlendirildiğinde, çalışma hayatında negatif duygulara eğilimli bireyler ile çalışma ihtimalini ortadan kaldırmak için örgütlere, işe alım süreçlerinde bu çalışmada bahsi geçen beş faktör kişilik özellikleri ölçeğini kişilik testleri olarak başvuru yapan adaylara uygulamalarının ve elde ettikleri sonuçlara göre işe alım yapmalarının sağlıklı bir örgüt ortamı ve örgüt iklimi oluşturmalarına katkı sağlayacağını söylemek mümkündür. Bununla birlikte örgütler, işe alım süreçlerinin yanı sıra çalışanların, çalışma hayatında negatif duygulara kapılmalarının önüne geçebilmek için öncelikle çalışma koşulları iyileştirilmeli, çalışanların karşılaşabileceği olası olumsuz durumlar öngörülerek önleyici girişimlerde bulunulmalı, çalışanların kişisel gelişimlerini geliştirici ve onların pozitif duygulara yönlendirici bir takım eğitimler ve pozitif etkileşimleri arttıran etkinlikler düzenlemeli ve örgütsel faaliyetler tasarlamalıdır. Ayrıca çalışanların pozitif duygularla hareket ederek etkinliğinin arttırılması için çalışanlara uygun çalışma ortamları hazırlanarak pozitif örgüt iklimi oluşturulmalıdır.

Araştırmanın sınırlılıkları arasında, çalışmanın sadece Kırşehir ilinden belirli bir örneklemden veri toplayarak ve belirli değişkenler çerçevesinde yapılması yer almaktadır. Bu bağlamda, gelecekte yapılacak çalışmalar için araştırmacıların, bu çalışmada doğrulanan bu yapıyı, daha farklı sektörlerde ve daha geniş örneklem gruplarında test etmeleri, beş faktör kişilik özelliklerinden farklı kişilik özellikleri ile pozitif ve negatif duygular arasındaki ilişkileri incelemeleri, kişilik özellikleri ve pozitif ve negatif duygulara etki veya aracılık edebilecek farklı değişkenler üzerinde de araştırma yapmaları gerek teoride literatürün genişlemesine gerekse de pratikte örgüt çevrelerine oldukça önemli katkılar sunacaktır.

\section{Kaynakça}

Abu Elanain, H. M. (2007). The five-factor model of personality and organizational citizenship behavior in United Arab Emirates. SAM Advanced Management Journal, 72(3), 47-57.

Alarcon, G., Eschleman, K. J. ve Bowling, N. A. (2009). Relationship between personality and burnout: A meta-analysis. Work \& Stress, 23(3), 244-263. 
Arslan, A. ve Yener, S. (2015). Temel benlik değerlendirmeleri-girişimci kişilik ilişkisinde ençoklamacı karar verme yaklaşımının aracı değişken rolü: Konya örneği. Işsletme Araştırmaları Dergisi, 7(3), 283-310.

Atak, H. (2013). On-Maddeli kişilik ölçeğinin Türk kültürüne uyarlanması. Nöropsikiyatri Arşivi, 50(4), 312-319.

Atkinson, R. C., Atkinson, R., Smith, E. E., Bem, D. J. ve Hoeksema, S. N. (2019). Psikolojiye giriş (Y. Alogan, Çev.). Ankara: Arkadaş Yayınları.

Bacanlı, H., İlhan, T. ve Aslan, S. (2009). Beş faktör kuramına dayalı bir kişilik ölçeğinin geliştirilmesi: Sifatlara dayalı kişilik testi (SDKT). Türk Ĕgitim Bilimleri Dergisi, 7(2), 261279.

Baş Atik, Z. (2018). Öğretmenlerin işle bütünleşme düzeylerinin beş faktör kişilik özellikleri, iş doyumu ve öznel iyi oluşla ilişsisi (Yayımlanmamış yüksek lisans tezi). Karadeniz Teknik Üniversitesi, Trabzon.

Basım, H. N., Çetin, F. ve Tabak, A. (2009). Beş faktör kişilik özelliklerinin kişilerarası çatışma çözme yaklaşımlarıyla ilişkisi. Türk Psikoloji Dergisi, 24(63), 20-34.

Benet-Martínez, V. ve John, O. P. (1998). Los Cinco Grandes across cultures and ethnic groups: Multitrait-multimethod analyses of the Big Five in Spanish and English. Journal of Personality and Social Psychology, 75(3), 729-750.

Bernerth, J. B., Armenakis, A. A., Feild, H. S., Giles, W. F. ve Walker, H. J. (2007). Is personality associated with perceptions of LMX? An empirical study. Leadership \& Organization Development Journal, 28(7), 613-631.

Bitlisli, F., Dinç, M., Çetinceli, E. ve Kaygısız, Ü. (2013). Beş faktör kişilik özellikleri ile akademik güdülenme ilişkisi: Süleyman Demirel Üniversitesi Isparta Meslek Yüksekokulu öğrencilerine yönelik bir araştırma. Süleyman Demirel Üniversitesi İktisadi ve İdari Bilimler Fakültesi Dergisi, 18(2), 459-480.

Bouchard, G., Guillemette, A. ve Landry-Léger, N. (2004). Situational and dispositional coping: An examination of their relation to personality, cognitive appraisals, and psychological distress. European Journal of Personality, 18(3), 221-238.

Burger, J. M. (2006). Kişilik. İstanbul: Kaknüs Yayınları.

Caldwell, D. F. ve Burger, J. M. (1998). Personality characteristics of job applicants and success in screening interviews. Personnel Psychology, 51(1), 119-136.

Can, Y., Çoban, Ü. ve Soyer, F. (2011). Negatif duygusallı̆̆ın stres üzerindeki etkisi: Faal futbol hakemleri üzerinde bir araştırma. Beden Eğitimi ve Spor Bilimleri Dergisi, 5(2), 165 174.

Çetin, F., Yeloğlu, H. O. ve Basım, H. N. (2015). Psikolojik dayanıklılı̆̆ın açıklanmasında beş faktör kişilik özelliklerinin rolü: Bir kanonik ilişki analizi. Türk Psikoloji Dergisi, 30(75), 81-92.

Clark, L. A. ve Watson, D. (1991). Tripartite model of anxiety and depression: Psychometric evidence and taxonomic implications. Journal of Abnormal Psychology, 100(3), 316-336.

Collins, A. ve Gunner, M. (1990). Social and personality development. Annual Review of Psychology, 41(1), 387-416.

Cooper, C. A., Golden, L. ve Socha, A. (2013). The big five personality factors and mass politics. Journal of Applied Social Psychology, 43(1), 68-82. 
Costa, P. T. ve McCrae, R. R. (1992a). Four ways five factors are basics. Personality and Individual Differences, 13(6), 653-665.

Costa, P. T. ve McCrae, R. R. (1992b). Normal personality assessment in clinical practice: The NEO Personality Inventory. Psychological Assessment, 4(1), 5-13.

Costa, P. T. ve McCrae, R. R. (1995). Domains and facets: Hierarchical personality assessment using the revised NEO personality inventory. Journal of Personality Assessment, 64(1), 2150.

Costa, P. T., Busch, C. M., Zonderman, A. B. ve McCrae, R. R. (1986). Correlations of MMPI factor scales with measures of the five factor model of personality. Journal of Personality Assessment, 50(4), 640-650.

Davidson, R. J. (1992). Anterior cerebral asymmetry and the nature of emotion. Brain and Cognition, 20(1), 125-151.

DeLongis, A. ve Holtzman, S. (2005). Coping in context: The role of stress, social support, and personality in coping. Journal of Personality, 73(6), 1633-1656.

Demirci, M. K., Özler, D. E. ve Girgin, B. (2007). Beş faktör kişilik modelinin işyerinde duygusal tacize (mobbing) etkileri-hastane işletmelerinde bir uygulama. Journal of Azerbaijani Studies, 10, 13-39.

Develioğlu, K. ve Tekin, Ö. A. (2013). Beş faktör kişilik özellikleri ve yabancılaşma arasındaki iliş̧ki: Beş yıldızlı otel çalışanları üzerinde bir araştırma. Süleyman Demirel Üniversitesi İktisadi ve Ídari Bilimler Fakültesi Dergisi, 18(2), 15-30.

Diener, E., Suh, E. ve Oishi, S. (1997). Recent findings on subjective well-being. Indian Journal of Clinical Psychology, 24, 25-41.

Digman, J. M. (1990). Personality structure: Emergence of the five factor model. Annual Review of Psychology, 41, 417-440.

Doğan, T. (2013). Beş faktör kişilik özellikleri ve öznel iyi oluş. Doğuş Üniversitesi Dergisi, 14(1), 56-64.

Eggers, J. H. (2000). Five-factor theory of personality: A new and useful lens to explore enterpreneurial action, or another useless dead-end? Journal of Private Equity, 4(1), 59-63.

Erkuş, A. ve Tabak, A. (2009). Beş faktör kişilik özelliklerinin çalışanların çatışma yönetim tarzlarına etkisi: Savunma sanayinde bir araştırma. Atatürk Üniversitesi İktisadi ve Ídari Bilimler Dergisi, 23(2), 213-242.

Eroğlu, F. (2017). Davranış bilimleri. İstanbul: Beta Basım Yayım Dağıtım AŞ.

Eysenck, S. B. ve Eysenck, H. J. (1969). Scores on three personality variables as a function of age, sex and social class. The British Journal of Social and Clinical Psychology, 8(1), 69-76.

Fredrickson, B. L. (2001). The role of positive emotions in positive psychology: The broadenand-build theory of positive emotions. American Psychologist, 56(3), 218-226.

Fujita, F. (1991). An investigation of the relation between extraversion, neuroticism, positive affect, and negative affect (Yayımlanmamış yüksek lisans tezi). University of Illinois, Urbana-Champaign.

Gençöz, T. (2000). Pozitif ve negatif duygu ölçeği: Geçerlik ve güvenirlik çalışması. Türk Psikoloji Dergisi, 15(46), 19-26.

Gökdeniz, İ. ve Merdan, E. (2011). Kişilik ile kariyer seçimi arasındaki ilişkinin incelenmesi. Aksaray Üniversitesi IIIBF Dergisi, 3(2), 23-36. 
Goldberg, L. R. (1992). The development of markers for the big-five factor structure. Psychological Assessment, 4(1), 26-42.

Gosling, S. D., Rentfrow, P. J. ve Swann Jr, W. B. (2003). A very brief measure of the Big-Five personality domains. Journal of Research in Personality, 37(6), 504-528.

Guthrie, J. P., Coate, C. J. ve Schwoerer, C. E. (1998). Career management strategies: The role of personality. Journal of Managerial Psychology, 13(5/6), 371-386.

Harmancı, Y. K. (2018). Örgütsel yaşamda kişilik ve performans ilişkisinde pozitif duygusallığın aracı rolü. İşletme Araştırmaları Dergisi, 10(1), 321-341.

Hirschfeld, R. R., Jordan, M. H., Thomas, C. H. ve Feild, H. S. (2008). Observed leadership potential of personnel in a team setting: Big five traits and proximal factors as predictors. International Journal of Selection and Assessment, 16(4), 385-402.

Işık, Ş. ve Üzbe, N. (2015). Personality traits and positive/negative affects: An analysis of meaning in life among adults. Educational Sciences: Theory \& Practice, 15(3), 587-595.

Johnson, J. A. ve Ostendorf, F. (1993). Clarification of the five-factor model with the Abridged Big Five Dimensional Circumplex. Journal of Personality and Social Psychology, 65(3), 563-576.

Judge, T. A., Higgins, C. A., Thoresen, C. J. ve Barrick, M. R. (1999). The big five personality traits, general mental ability, and career success across the life span. Personnel Psychology, 52(3) 621-652.

Keleş, Y. (2019). Duygusal emek kişilik özellikleri ile ilişkili mi? Otel çalışanları üzerine bir araştırma. Afyon Kocatepe Üniversitesi Sosyal Bilimler Dergisi, 21(1), 257-267.

Lau, V. P. ve Shaffer, M. A. (1999). Career success: The effects of personality. Career Development International, 4(4), 225-231.

Leung S. L. ve Bozionelos, N. (2004). Five-factor model traits and the prototypical image of the effective leader in the Confucian culture. Employee Relations, 26(1), 62-71.

Lim, B. C. ve Ployhart, R. E. (2004). Transformational leadership: Relations to the five-factor model and team performance in typical and maximum contexts. The Journal of Applied Psychology, 89(4), 610-621.

Lounsbury, J. W., Tatum, H. E., Chambers, W. Owens, K. S. ve Gibson, L. W. (1999). An investigation of career decidedness in relation to 'Big Five' personality constructs and life satisfaction. College Student Journal, 33(4), 646-652.

Lucas, R. E. ve Fujita, F. (2000). Factors influencing the relation between extraversion and pleasant affect. Journal of Personality and Social Psychology, 79(6), 1039-1056.

Lyubomirsky, S., King, L. A. ve Diener, E. (2005). The benefits of frequent positive affect. Psychological Bulletin, 131(6), 803-855.

Mc Adams, D. P. (1997). A conceptual history of personality psychology. R. H. J. Johnson ve S. Briggs (Ed), Handbook of personality psychology içinde (ss. 3-39). Academic Press.

McCormack, L. ve Mellor, D. (2002). The Role of personality in leadership: An application of the five-factor model in the Australian military. Military Psychology, 14(3), 179-197.

McCrae, R. R. ve Costa, P. T. (1987). Validation of the five-factor model of personality across instruments and observers. Journal of Personality and Social Psychology, 52(1), 81-90.

McCrae, R. R. ve Costa, P. T. (1991). The NEO personality inventory: Using the five-factor model in counseling. Journal of Counseling \& Development, 69(4), 367-372. 
McCrae, R. R. ve Costa, P. T. (2003). Personality in adulthood: A five-factor theory perspective. New York: Guilford Press.

McCrae, R. R. ve Costa, P. T. (2006). A five-factor theory perspective on traits and culture. Psychologie Française, 51(3), 227-244.

McCrae, R. R. ve John, O. P. (1992). An introduction to the five-factor model and its applications. Journal of Personality, 60(2), 175-215.

Merdan, E. (2013). Beş faktör kişilik kuramı ile iş değerleri ilişkisinin incelenmesi: Bankacılık sektöründe bir araştırma. Gümüşhane Üniversitesi Sosyal Bilimler Enstitüsü Elektronik Dergisi, 4(7), 140-159.

Morgan, C. T. (2011). Psikolojiye giriş (S. Karakaş ve R. Eski, Çev. Ed). Konya: Eğitim Yayınevi.

Oğuzkan, A. F. (1981). Eğitim terimleri sözlüğ̈̈ (2. bask1). Ankara: TDK Yayınlar1.

Ordun, G. (2004). Beş temel kişilik özelliği ve alt faktörlerinin analizine ilişkin bir çalışma. İstanbul Üniversitesi Işsletme Fakültesi Dergisi, 33(2), 47-71.

Özdemir, A. A. (2015). İş tatmini, pozitif/negatif duygulanım ve yaşam tatmininin etkisi. Çalışma ve Toplum, 46(3), 47-61.

Paulson, D. ve Leuty, M. E. (2016). Dispositional coping, personality traits, and affective style relating to conflict between work and family domains. Journal of Family and Economic Issues, 37(4), 519-539.

Pınar, Y. ve Pınar, N. K. (2015). İlk dil edinim kuramlarında duygulanım ve duygu olgularının yeri. Journal of Human Sciences, 12(2), 343-359.

Russel, J. (1980). A circumplex model of affect. Journal of Personality and Social Psychology, 39(6), 1161-1178.

Shi, J. Lin, H. Wang, L. ve Wang, M. (2009). Linking the big five personality constructs to organizational justice. Social Behavior and Personality, 37(2), 209-222.

Sığrı, Ü. ve Gürbüz, S. (2011). Akademik başarı ve kişilik ilişkisi: Üniversite öğrencileri üzerinde bir araştırma. Savunma Bilimleri Dergisi, 10(1), 30-48.

Şimşek, M. Ş., Çelik, A. ve Akgemci, T. (2014). Davranış bilimlerine giriş ve örgütlerde davranış. Konya: Eğitim Yayınevi.

Sneed, C. D. (2002). Correlates and implications for agreeableness in children. The Journal of Psychology, 136(1), 59-67.

Somer, O. (1998). Türkçede kişilik özelliğini tanımlayan sıfatların yapısı ve beş faktör analizi. Türk Psikoloji Dergisi, 13(42),17-32.

Somer, O. ve Goldberg, L. R. (1999). The structure of Turkish trait-descriptive adjectives. Journal of Personality and Social Psychology, 76(3), 431-450.

Somer, O., Korkmaz, M. ve Tatar, A. (2002). Beş faktör kişilik envanterinin geliştirilmesi-I: Ölçek ve alt ölçeklerin oluşturulması. Türk Psikoloji Dergisi, 17(49), 21-36.

Sudak, M. K. ve Zehir, C. (2013). Kişilik tipleri, duygusal zeka, iş tatmini ilişkisi üzerine yapılan bir araştırma. Yönetim Bilimleri Dergisi, 11(22), 141-165.

Sung, S. Y. ve Choi, J. N. (2009). Do big five personality factors affect individual creativity? The moderating role of extrinsic motivation. Social Behavior and Personality: An International Journal, 37(7), 941-956. 
Thoms, P., Moore, K. S. ve Scott, K. (1996). The Relationship between self-efficacy for participating in self-managed work groups and the big five personality dimensions. Journal of Organizational Behavior, 17(4), 349-362.

Tommasel, A., Corbellini, A., Godoy, D. ve Schiaffino, S. (2015). Exploring the role of personality traits in followee recommendation. Online Information Review, 39(6), 812-830.

Töremen, F. ve Çankaya, İ. (2008). Yönetimde etkili bir yaklaşım: Duygu yönetimi. Kuramsal Ë̆itimbilim, 1(1), 33-47.

Ünsal, P. ve Türetgen, İ. Ö. (2013). Mülakatçıların kişilik özellikleri, olumlu ve olumsuz duygu durumları ve aday karşılaştırma olanağının seçim mülakat sonuçları üzerindeki etkisi. Türk Psikoloji Dergisi, 28(72), 86-98.

Vakola, M., Tsaousis, I. ve Nikolaou, I. (2004). The role of emotional intelligence and personality variables on attitudes toward organisational change. Journal of Managerial Psychology, 19(2), 88-110.

Watson, D. ve Clark, L. A. (1997). Extraversion and its positive emotional core. R. Hogan, J. Johnson, ve S. Briggs (Eds.), Handbook of Personality Psychology içinde (ss. 767-793). San Diego, CA: Academic Press.

Watson, D. ve Clark, L.A. (1992). On traits and temperament: General and specific factors of emotional experience and their relation to the five-factor model. Journal of Personality, 60(2), 441-476.

Watson, D. ve Tellegen, A. (1985). Toward a consensual structure of mood. Psychological Bulletin, 98(2), 219-235.

Watson, D., Clark, L. A. ve Tellegen, A. (1984). Cross-cultural convergence in the structure of mood: A Japanese replication and a comparison with US findings. Journal of Personality and Social Psychology, 47(1), 127-144.

Watson, D., Clark, L. A. ve Tellegen, A. (1988). Development and validation of brief measures of positive and negative affect: The PANAS scales. Journal of Personality and Social Psychology, 54(6), 1063-1070.

Wayne, J. H., Musisca, N. ve Fleeson, W. (2004). Considering the role of personality in the work-family experience: Relationships of the big five to work-family conflict and facilitation. Journal of Vocational Behavior, 64(1), 108-130.

Weiss, H. M. ve Cropanzano, R. (1996). Affective Events Theory: A theoretical discussion of the structure, causes and consequences of affective experiences at work. B. M. Staw ve L. L. Cummings (Eds), Research in organizational behavior: An annual series of analytical essays and critical reviews içinde (ss. 1-74). Elsevier Science/JAI Press.

Witt, L. A., Andrews, M. C. ve Carlson, D. S. (2002). When conscientiousness isn't enough: Emotional exhaustion and performance among call center customer service representative. Journal of Management, 30(1), 149-160.

Yamane, T. (2001). Temel örnekleme yöntemleri (1. Baskı). (A. Esin, M. A. Bakır, C. Aydın ve E. Gürbüzsel, Çev.). İstanbul: Literatür Yayıncılık.

Yener, S., Arslan, A. ve Demirtaş, Ö. (2018). The mediating role of temperament and character on the relationship between mindfulness and entrepreneurial personality. JEEMS Journal of East European Management Studies, 23(3), 404-425.

Zellars, K. L., Perrew, P. L. ve Hochwarter, W. A. (2000). Burnout in health care: The role of the five factors of personality. Journal of Applied Social Psychology, 30(8), 1570-1598. 
Zevon, M. A. ve Tellegen, A. (1982). The structure of mood change: An idiographic/nomothetic analysis. Journal of Personality and Social Psychology, 43(1), 111-122.

http://www.tdk.gov.tr.

\section{ETİK ve BİLIMSEL İLKELER SORUMLULUK BEYANI}

$\mathrm{Bu}$ çalışmanın tüm hazırlanma süreçlerinde etik kurallara ve bilimsel atıf gösterme ilkelerine riayet edildiğini yazar(lar) beyan eder. Aksi bir durumun tespiti halinde Afyon Kocatepe Üniversitesi Sosyal Bilimler Dergisi'nin hiçbir sorumluluğu olmayıp, tüm sorumluluk makale yazarlarına aittir. Yazarlar etik kurul izni gerektiren çalışmalarda, izinle ilgili bilgileri (kurul adı, tarih ve sayı no) yöntem bölümünde ve ayrıca burada belirtmişlerdir.

Kurul adı: Kırşehir Ahi Evran Üniversitesi, Sosyal ve Beşeri Bilimler Bilimsel Araştırma ve Yayın Etik Kurulu

Tarih: 01/07/2020

No: $2020 / 2$

\section{ARAŞTIRMACILARIN MAKALEYE KATKI ORANI BEYANI}

1. yazar katk1 oranı : $\% 50$

2. yazar katk1 oran1 : $\% 50$ 